\title{
SCIENTIFIC REP RTS OPEN Author Correction: Control of in vivo ictogenesis via endogenous
synaptic pathways
} Hiram Luna-Munguia ${ }^{1}$, Phillip Starski ${ }^{1}$, Wu Chen ${ }^{1}$, Stephen Gliske $\mathbb{B}^{1}$ \& William C. Stacey $\mathbb{D}^{1,2}$

Scientific Reports 7:1311; doi:10.1038/s41598-017-01450-8; Article published online 02 May 2017

The original version of this Article contained a typographical error in the spelling of the author Phillip Starski which was incorrectly given as Philip Starski. This has now been corrected in the PDF and HTML versions of the Article.

(i) Open Access This article is licensed under a Creative Commons Attribution 4.0 International License, which permits use, sharing, adaptation, distribution and reproduction in any medium or format, as long as you give appropriate credit to the original author(s) and the source, provide a link to the Creative Commons license, and indicate if changes were made. The images or other third party material in this article are included in the article's Creative Commons license, unless indicated otherwise in a credit line to the material. If material is not included in the article's Creative Commons license and your intended use is not permitted by statutory regulation or exceeds the permitted use, you will need to obtain permission directly from the copyright holder. To view a copy of this license, visit http://creativecommons.org/licenses/by/4.0/.

(C) The Author(s) 2017

${ }^{1}$ Department of Neurology, University of Michigan, Ann Arbor, MI, 48109, USA. ${ }^{2}$ Department of Biomedical Engineering, University of Michigan, Ann Arbor, MI, 48109, USA. Correspondence and requests for materials should be addressed to W.C.S. (email: william.stacey@umich.edu) 